\title{
Effect of Bunch Feeding on Reproductive Parameters, Bunch Parameters, Hand Parameters and Fingers Parameters in Banana cv. Rajapuri (Musa AAB)
}

\author{
Soumya M. Garasangi*, S.I. Athani, Hipparagi, Kulapati, J.B. Gopali, \\ T.B. Allolli and Mallikarjun Awati
}

University of Horticultural Sciences, Bagalkot, Karnataka, India

*Corresponding author

A B S T R A C T

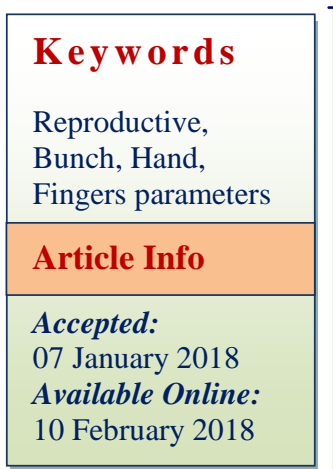

\section{Introduction}

Banana is one of the important fruit crop of India. The name banana comes from the Arabic word 'BANANA', which means finger. Banana is also known by other synonyms like 'Adam's fig', 'Kalpataru', 'Tree of wisdom' and 'Apple of Paradise'. Banana (Musa spp) is one of the major commercial fruit crops grown in the tropics, subtropics and plays a key role in the economy of developing countries. In India it is cultivated throughout the year. Among the banana varieties grown, the cultivar 'Rajapuri' belongs to the Musa AAB group is one of the popular varieties among growers and
An investigation was carried out in farmers' field in Savadatti taluk of Belgaum district on bunch feeding in banana cv. Rajapuri. Bunch fed with combination of $500 \mathrm{ml}$ of cow dung slurry and $20 \mathrm{~g}$ of $\mathrm{K}_{2} \mathrm{SO}_{4}\left(\mathrm{~T}_{3}\right)$ showed increased values bunch length $(57.47 \mathrm{~cm})$, internodal length $(13.84 \mathrm{~cm})$, bunch shape index $(109.44 \mathrm{~cm})$, number of hands per bunch (9.08), weight of hand $(1.79 \mathrm{~kg})$, finger length $(15.91 \mathrm{~cm})$, finger girth $(12.68 \mathrm{~cm})$, finger weight $(141.50 \mathrm{~g})$, pulp weight $(75.54 \mathrm{~g})$, peel weight $(27.32 \mathrm{~g})$, pulp to peel ratio (2.76) and bunch weight $(13.20 \mathrm{~kg})$ with lesser number of days (120.66) taken from shooting to varvesting, while minimum values for all these parameters were noticed in $\mathrm{T}_{10}$ (controlounch stalk feeding) Thus, the study clearly indicates that bunch feeding with 500 $\mathrm{ml}$ of cow dung slurry and $20 \mathrm{~g}$ of $\mathrm{K}_{2} \mathrm{SO}_{4}$ improves the reproductive characters, finger characters, hand characters and bunch characters of banana cv. Rajapuri (Musa AAB).

consumers, particularly in Karnataka and Kerala for domestic markets. Banana has many varieties but among those, local or indigeneous cultivars are more tolerant to biotic and abiotic stresses and suitable to local agro-climatic conditions.

Nutrients are supplied to the banana plant through soil and foliage, by de-navelling (removal of male inflorescence) and feeding nutrients post shooting through the distal stalk-end of rachis (Ancy and Kurein, 2000). De-navelling serves the twin purpose of saving mobilization of food into an unwanted sink plant and earning an additional income when the excised male bud is used as 
vegetable. Further, it also facilitates bunch feeding with nutrients through cut end of rachis (Singh, 2001). Further, the fruit quality is determined by size (finger length and finger girth), evenness of ripening, free from blemishes and defects and arrangement of hands are also favorably influenced by this technique. Hence, the technology of bunch feeding in banana is very useful in improving the growth, yield and quality of the fruit.

\section{Materials and Methods}

The research was conducted during 2016-17, in the farmer's field at Tadasalur, near Yaragatti, Savadatti taluq, Belgaum district in banana cv. Rajapuri. The experiment was laid out in a Randomized Complete Block Design (RCBD) with ten treatments, replicated thrice. The treatment details are:

$\mathrm{T}_{1}: 500 \mathrm{ml}$ of cow dung slurry $+20 \mathrm{~g}$ of $\mathrm{KNO}_{3}$

$\mathrm{T}_{2}: 500 \mathrm{ml}$ of cow dung slurry $+10 \mathrm{~g}$ of Urea

$\mathrm{T}_{3}$ : $500 \mathrm{ml}$ of cow dung slurry $+20 \mathrm{~g}$ of $\mathrm{K}_{2} \mathrm{SO}_{4}$

$\mathrm{T}_{4}: 500 \mathrm{ml}$ of cow dung slurry $+25 \mathrm{mg}$ of $\mathrm{GA}_{3}$

$\mathrm{T}_{5}: 500 \mathrm{ml}$ of cow dung slurry $+15 \mathrm{mg}$ of 2 , 4-D

$\mathrm{T}_{6}$ : $500 \mathrm{ml}$ of cow dung slurry $+12.5 \mathrm{~g}$ of Sulphate of potash (SOP)

$\mathrm{T}_{7}: 500 \mathrm{ml}$ of cow dung slurry $+10 \mathrm{~g}$ of Ammonium sulphate

$\mathrm{T}_{8}: 500 \mathrm{ml}$ of cow dung slurry

$\mathrm{T}_{9}: 500 \mathrm{ml}$ of cow dung slurry $+10 \mathrm{~g}$ of Urea $+20 \mathrm{~g}$ of $\mathrm{K}_{2} \mathrm{SO}_{4}+15 \mathrm{mg}$ of $\mathrm{GA}_{3}$

$\mathrm{T}_{10}$ : Control (without bunch stalk feeding) The prepared solution was placed in the thick polythene bag and tied to the cut end of denavelled bunch immediately. The denavelling was carried out soon after all the pistillate flowers have set fruits i.e., 15 days after flower emergence and maintained till harvest.

\section{Study parameters included}

Reproductive parameters, length of bunch at harvest $(\mathrm{cm})$, internodal length between hands $(\mathrm{cm})$, bunch shape index $(\mathrm{cm})$, number of hands per bunch (no), weight of hand (kg), finger length $(\mathrm{cm})$, finger girth $(\mathrm{cm})$, finger weight $(\mathrm{g})$, pulp weight $(\mathrm{g})$, peel weight $(\mathrm{g})$, pulp to peel ratio, and bunch weight $(\mathrm{kg})$.

Weight of the bunch was recorded including the peduncle up to first bract leaf node above the first hand and expressed in kilogram. The total plant yield was calculated by multiplying the yield per plant with the total number of plants per hectare and expressed in tones.

The middle fingers in the top and bottom rows of the second hand were selected as representative fingers (Gottreich et al., 1964) to record finger length $(\mathrm{cm})$, finger girth $(\mathrm{cm})$ and average weight of the finger (gram). The data was statistically analyzed by method of analysis of variance using RCBD as described by Fisher and Yates (1963).

\section{Results and Discussion}

The days taken from shooting to harvest and bunch parameters have shown significant difference among the treatments (Table 1). The lowest number of days (120.66 days) were taken from shooting to harvesting was in $\mathrm{T}_{3^{-}}$bunch fed with $500 \mathrm{ml}$ of cow dung slurry and $20 \mathrm{~g}$ of $\mathrm{K}_{2} \mathrm{SO}_{4}$ and maximum number of days from shooting to harvesting was recorded in control $\mathrm{T}_{10}$. Additional $\mathrm{K}$ application through the bunch stalk end application induced the early and faster development of bunches. 
Table.1 Effect of bunch feeding on reproductive and bunch parameters of banana cv. Rajapuri

\begin{tabular}{|c|c|c|c|c|c|}
\hline Treatment & $\begin{array}{l}\text { Days taken } \\
\text { from shooting } \\
\text { to harvest }\end{array}$ & $\begin{array}{l}\text { Internodal } \\
\text { length }(\mathrm{cm})\end{array}$ & $\begin{array}{c}\text { Bunch length } \\
\text { (cm) }\end{array}$ & $\begin{array}{l}\text { Bunch Shape } \\
\text { Index }(\mathrm{cm})\end{array}$ & $\begin{array}{c}\text { Bunch weight } \\
\text { (kg) }\end{array}$ \\
\hline $\mathrm{T}_{1}$ : Cow dung slurry $500 \mathrm{ml}+\mathrm{KNO}_{3} 20 \mathrm{~g}$ & 121.33 & 12.28 & 46.11 & 100.97 & 12.73 \\
\hline $\mathrm{T}_{2}$ : Cow dung slurry $500 \mathrm{ml}+$ Urea $10 \mathrm{~g}$ & 122.41 & 12.12 & 42.62 & 100.50 & 11.91 \\
\hline $\mathrm{T}_{3}$ : Cow dung slurry $500 \mathrm{ml}+\mathrm{K}_{2} \mathrm{SO}_{4} 20 \mathrm{~g}$ & 120.66 & 13.84 & 57.47 & 109.44 & 13.20 \\
\hline $\mathrm{T}_{4}$ : Cow dung slurry $500 \mathrm{ml}+\mathrm{GA}_{3} 25 \mathrm{mg}$ & 125 & 11.09 & 42.69 & 100.89 & 10.86 \\
\hline $\mathrm{T}_{5}:$ Cow dung slurry $500 \mathrm{ml}+2,4-\mathrm{D} 15 \mathrm{mg}$ & 126.33 & 11.64 & 42.33 & 91.00 & 10.96 \\
\hline $\mathrm{T}_{6}:$ Cow dung slurry $500 \mathrm{ml}+$ SOP $12.5 \mathrm{~g}$ & 123.66 & 12.63 & 48.44 & 109.03 & 13.11 \\
\hline $\mathrm{T}_{7}$ : Cow dung slurry $500 \mathrm{ml}+$ ammonium sulphate $10 \mathrm{~g}$ & 121.75 & 12.52 & 48.18 & 102.19 & 13.06 \\
\hline $\mathrm{T}_{8}$ : Cow dung slurry $500 \mathrm{ml}$ & 125.25 & 11.75 & 41.83 & 97.94 & 13.11 \\
\hline $\mathrm{T}_{9}:$ Cow dung slurry $500 \mathrm{ml}+10 \mathrm{~g}$ urea $+20 \mathrm{~g} \mathrm{~K}_{2} \mathrm{SO}_{4}+25 \mathrm{mg} \mathrm{GA}_{3}$ & 124.83 & 12.20 & 43.80 & 100.81 & 11.17 \\
\hline$T_{10}:$ Control (Without bunch stalk feeding) & 127.66 & 10.01 & 41.28 & 88.06 & 9.33 \\
\hline S.Em \pm & 0.67 & 0.43 & 1.59 & 3.90 & 0.70 \\
\hline CD at $5 \%$ & 1.99 & 1.28 & 4.72 & 11.57 & 2.07 \\
\hline
\end{tabular}

Table.2 Effect of bunch feeding on hand parameters of banana cv. Rajapuri

\begin{tabular}{|c|c|c|}
\hline Treatments & Number of hands per bunch & Hand weight (kg) \\
\hline $\mathrm{T}_{1}$ : Cow dung slurry $500 \mathrm{ml}+\mathrm{KNO}_{3} 20 \mathrm{~g}$ & 8.83 & 1.68 \\
\hline $\mathrm{T}_{2}:$ Cow dung slurry $500 \mathrm{ml}+$ Urea $10 \mathrm{~g}$ & 8.33 & 1.45 \\
\hline $\mathrm{T}_{3}$ : Cow dung slurry $500 \mathrm{ml}+\mathrm{K}_{2} \mathrm{SO}_{4} 20 \mathrm{~g}$ & 9.08 & 1.79 \\
\hline $\mathrm{T}_{4}$ : Cow dung slurry $500 \mathrm{ml}+\mathrm{GA}_{3} 25 \mathrm{mg}$ & 8.25 & 1.14 \\
\hline $\mathrm{T}_{5}$ : Cow dung slurry $500 \mathrm{ml}+2,4-\mathrm{D} 15 \mathrm{mg}$ & 8.58 & 1.22 \\
\hline $\mathrm{T}_{6}$ : Cow dung slurry $500 \mathrm{ml}+\mathrm{SOP} 12.5 \mathrm{~g}$ & 8.83 & 1.20 \\
\hline $\mathrm{T}_{7}$ : Cow dung slurry $500 \mathrm{ml}+$ ammonium sulphate $10 \mathrm{~g}$ & 8.50 & 1.63 \\
\hline $\mathrm{T}_{8}$ : Cow dung slurry $500 \mathrm{ml}$ & 8.58 & 1.37 \\
\hline $\mathrm{T}_{9}:$ Cow dung slurry $500 \mathrm{ml}+10 \mathrm{~g}$ urea $+20 \mathrm{~g} \mathrm{~K}_{2} \mathrm{SO}_{4}+25 \mathrm{mg} \mathrm{GA}$ & 8.75 & 1.39 \\
\hline $\mathrm{T}_{10}:$ Control (Without bunch stalk feeding) & 8.83 & 1.06 \\
\hline S.Em \pm & 0.18 & 0.10 \\
\hline CD at $5 \%$ & NS & 0.30 \\
\hline
\end{tabular}
NS: Non-Significant 
Table.3 Effect of bunch feeding on finger parameters of banana cv. Rajapuri

\begin{tabular}{|c|c|c|c|c|c|c|}
\hline Treatment & $\begin{array}{c}\text { Finger } \\
\text { length } \\
\text { (cm) }\end{array}$ & $\begin{array}{l}\text { Finger } \\
\text { girth } \\
(\mathrm{cm})\end{array}$ & $\begin{array}{l}\text { Finger } \\
\text { weight } \\
\text { (g) }\end{array}$ & $\begin{array}{c}\text { Pulp } \\
\text { weight } \\
\text { (g) }\end{array}$ & $\begin{array}{l}\text { Peel } \\
\text { weight } \\
(\mathrm{g})\end{array}$ & $\begin{array}{l}\text { Pulp to } \\
\text { peel } \\
\text { ratio }\end{array}$ \\
\hline $\mathrm{T}_{1}$ : Cow dung slurry $500 \mathrm{ml}+\mathrm{KNO}_{3} 20 \mathrm{~g}$ & 14.68 & 12.15 & 78.36 & 64.19 & 25.07 & 2.55 \\
\hline $\mathrm{T}_{2}$ : Cow dung slurry $500 \mathrm{ml}+$ Urea $10 \mathrm{~g}$ & 12.62 & 10.97 & 69.69 & 63.57 & 23.64 & 2.68 \\
\hline $\mathrm{T}_{3}$ : Cow dung slurry $500 \mathrm{ml}+\mathrm{K}^{2} \mathrm{SO}_{4} 20 \mathrm{~g}$ & 15.91 & 12.68 & 141.50 & 75.54 & 27.32 & 2.76 \\
\hline $\mathrm{T}_{4}:$ Cow dung slurry $500 \mathrm{ml}+\mathrm{GA}_{3} 25 \mathrm{~g}$ & 12.91 & 11.72 & 70.28 & 58.24 & 22.63 & 2.63 \\
\hline $\mathrm{T}_{5}:$ Cow dung slurry $500 \mathrm{ml}+2,4-\mathrm{D} 15 \mathrm{mg}$ & 13.42 & 11.28 & 65.83 & 61.95 & 22.76 & 2.72 \\
\hline $\mathrm{T}_{6}:$ Cow dung slurry $500 \mathrm{ml}+\mathrm{SOP} 12.5 \mathrm{~g}$ & 15.25 & 12.32 & 98.83 & 70.39 & 26.08 & 2.69 \\
\hline $\mathrm{T}_{7}$ : Cow dung slurry $500 \mathrm{ml}+$ ammonium sulphate $\mathbf{1 0} \mathrm{g}$ & 14.75 & 12.38 & 94.83 & 65.13 & 24.04 & 2.71 \\
\hline $\mathrm{T}_{8}:$ Cow dung slurry $500 \mathrm{ml}$ & 13.03 & 11.85 & 74.39 & 62.74 & 23.48 & 2.67 \\
\hline $\mathrm{T}$ 9: Cow dung $500 \mathrm{~g}+$ urea $10 \mathrm{~g}+\mathrm{K}_{2} \mathrm{SO}_{4} 20 \mathrm{~g}+25 \mathrm{mg} \mathrm{GA3}$ & 12.18 & 11.36 & 65.44 & 59.95 & 22.67 & 2.64 \\
\hline $\mathrm{T}_{10}:$ Control (Without bunch stalk feeding) & 10.77 & 9.78 & 46.56 & 57.89 & 22.58 & 2.56 \\
\hline S.Em. \pm & 0.57 & 0.53 & 3.20 & 2.94 & 0.87 & 0.16 \\
\hline CD at $5 \%$ & 1.68 & 1.58 & 9.50 & 8.75 & 2.59 & NS \\
\hline
\end{tabular}

NS: Non-Significant 
The above findings was corroborated with the findings of Ramesh Kumar et al., (2008) in cv. Robusta.

The maximum internodal length between hands of bunches, bunch length and bunch shape index $(13.84 \mathrm{~cm}, 57.47 \mathrm{~cm}$, and $109.44 \mathrm{~cm}$ respectively) were recorded in $\mathrm{T}_{3^{-}}$bunch fed with $500 \mathrm{ml}$ of cow dung slurry and $20 \mathrm{~g}$ of $\mathrm{K}_{2} \mathrm{SO}_{4}$, while, the minimum internodal length between hands bunch length and bunch shape index $(10.01 \mathrm{~cm}, 41.28 \mathrm{~cm}$ and $88.06 \mathrm{~cm}$ respectively) were recorded in the $\mathrm{T}_{10^{-}}$control (plant without bunch feeding). The increased length of bunches, internodal length between hands and bunch shape index might be due to additonal supply of Potassium which helps in cell division and cell expansion by their effect on RNA and DNA synthesis (Mostafa, 2005). Hence, internodal length between hands and length of bunch was increased in the cv. Rajapuri. The result of the present investigation is in confirmity with the findings of Geetha et al., (2015) in cv. Grand Naine under hill zone of Karnataka and Ramesh Kumar and Kumar (2007) in cv. Ney Poovan.

The data pertaining to the number of hands per bunch as influenced by bunch feeding did not differ significantly, whereas significantly increased hand weight was noticed in $\mathrm{T}_{3}$ - bunch fed with dipping the cut end in the $500 \mathrm{ml}$ of cow dung slurry $+20 \mathrm{~g}$ of $\mathrm{K}_{2} \mathrm{SO}_{4}$ recorded the highest $(1.79 \mathrm{~kg})$ hand weight (Table 2) and minimum hand weight $(1.06 \mathrm{~kg})$ was noticed in $\mathrm{T}_{10}$ (control).

Increase in weight of the hand might be attributed to the formation of higher sink capacity by retention of more carbohydrates and also the translocation of carbohydrates from other parts to reproductive parts during development (Duragannavara et al., 2009), which confirms the result of present investigation.

Except pulp to peel ratio, other finger parameters differed significantly among the treatments (Table 3). The Maximum finger length $(15.91 \mathrm{~cm})$, finger girth $(12.68 \mathrm{~cm})$, finger weight $(141.5 \mathrm{~g})$, pulp weight $(75.54 \mathrm{~g})$ and peel weight $(27.32 \mathrm{~g})$ were significantly observed in $\mathrm{T}_{3}$ (bunch fed with dipping the cut end in the $500 \mathrm{ml}$ of cow dung slurry $+20 \mathrm{~g}$ of $\mathrm{K}_{2} \mathrm{SO}_{4}$, whereas minimum values of finger length $(10.77 \mathrm{~cm})$, finger girth $(9.78 \mathrm{~cm})$, finger weight (46.56 g), pulp weight $(57.89 \mathrm{~g})$ and peel weight $(22.58 \mathrm{~g})$ were noticed in $\mathrm{T}_{10}$ (control) end in the cow dung slurry $+20 \mathrm{~g}$ of $\mathrm{K}_{2} \mathrm{SO}_{4}$.

The results of this investigation were in close confirmity with the findings of Ancy and Kurein (2000) in cv. Nendran, Ramesh Kumar and Kumar (2007) in cv. Ney Poovan and Nandankumar et al., (2011) in cv. Nanjangudu rasabale (AAB), who have reported that nutrients supplied would have been utilized for cell elongation of fruits and formation of larger intercellular spaces during later part of fruit growth.

The increase in finger girth inturn reflected on final weight of the finger, which clearly indicated that potassium is involved in cell enlargement rather than cell division as there was not much increase in length of fruit when compared to other treatments (Nandankumar et al., 2011 in cv. Nanjanagudu rasabale). The increase in finger girth might be due to the exogenous potassium supply, which acted as an activator of several enzymes. Potassium also had a role in synthesizing the precursor of chlorophyll pigments. Presence of sulphur in sulphate of potash has a synergistic effect with zinc, which is essential for cabon dioxide absorption and utilization, synthesis of RNA and auxin which increased the girth of fruit. Similar observations made by Mustaffa et al., (2004) in cv. Nendran, Ramesh Kumar and Kumar (2007) in cv. Neypoovan and Sarma et al.,(2014) in cv. Borjahaji.

The results obtained from the present investigation, on bunch weight revealed that, $\mathrm{T}_{3}$ - bunch fed with dipping the cut end in the $500 \mathrm{ml}$ of cow dung slurry $+20 \mathrm{~g}$ of $\mathrm{K}_{2} \mathrm{SO}_{4}$ recorded the highest bunch weigth $(13.20 \mathrm{~kg})$ and minimum bunch weight $(9.33 \mathrm{~kg})$ was 
noticed in control $\mathrm{T}_{10}$ (control- without bunch stath feeding) (Table 4). In the present study, application of sulphate of potash improved bunch weight and the findings are in corroboration with the results of Pandey and Sinha (1999), who have reported that the increase in weight of the bunch due to sulphur present in the sulphate of potash which might be responsible for the formation of ferridoxin (iron-sulphur protein) in plants which may have a direct impact in activating the catalase and peroxidase enzymes. Sulphur application increased the yield since it is a constituent of amino acid and protein production (Ahmed et al., 1998).

\section{References}

Ahmed, M. K., Aditya, D. K. and Siddique, M. A., 1998, Effect of $\mathrm{N}$ and $\mathrm{S}$ application on the growth and yield of onion cv. Faridpur Bhatti. Bangladesh Hort., 16(1): 36-41.

Ancy, K. and Kurien, S., 2000, Bunch stalk feeding of urea in banana Musa (AAB group) 'Nendran'. Sci. Hort., 84: 205212.

Duragannavara, M.P, Patil, C.P. and Patil, P.B. 2009. Influence of Glomus fasciculatum and bioformulations on shelf life, quality and yield of papaya cv. Red lady. Mycorrhiza News. 21(3): 20-23.

Geetha, S.S., Thippesha, D., Sreekanth, H.S. and Shwetha, B.S., 2015, Effect of foliar spray of urea and potash on bunch maturity and yield of tissue culture banana cv Grand Naine under hill zone of Karnataka, India. Environ and Eco., 33(3): 1167-1171.

Gottreich, M., Bradu, D. and Haleway, Y. 1964, A simple method for determining average fruit weight. Ktavim. 14: 161-162 (C.F.:
Lahav, E. 1972. Trop. Agric. 49: 321325).

Mustafa, E.A.M. 2005, Response of Williams banana to different rates of nitrogen and potassium fertilizers. J. App. Sci. Res., 1(1): 67-71.

Mustaffa, M. M., Tanuja, B., Sivakumar, K. C., Kumar, V. and Sathiamoorthy, S., 2004, Effect of preharvest treatments on bunch parameters, quality and shelf life of banana cv. Nendran. In Banana: Technological Advancements (Singh, H.P., and Uma, S. Eds), AIPUB, Trichy, pp. 124-132.

Nandankumar, C. P., Sathyanarayana, B. N., Naresh, P. and Lakshmipathy, M., 2011, Effect of certain pre harvest treatments in improving the yield and quality of banana cv. Nanjangudu rasabale. Pl. Arc., 11(2): 677-681.

Pandey, S. N. and Sinha, B. K., 1999, Plant Physiology. Vikas Publ. House Pvt. Ltd., New Delhi.

Ramesh Kumar, A., Kumar, N. and Jeyakumar, P., 2008, Effect of Post-shooting Spray of sulphate of potash (SOP) on yield and quality of Banana cv. Robusta (AAACavendish). Res. J. Agri. Bio. Sci., 4(6): 655-659.

Ramesh Kumar. A. and Kumar. N., 2007, Sulfate of Potash Foliar Spray Effects on Yield, Quality, and Post-Harvest Life of Banana. Better Crops., 91(2): 22-24.

Sarma, I., Borgohain, R. and Phukon, M., 2014, Effect of post shooting application of urea and sulphate of potash at the denavelled, distal stalk end of banana cv. Borjahaji. Asian J.Bio. Sci., 9(2): 296-298.

Singh, H.P., 2001, Banana. In: Handbook of Horticulture, ICAR publication, New Delhi. 152.

\section{How to cite this article:}

Soumya M. Garasangi, S.I. Athani, Hipparagi, Kulapati, J.B. Gopali, T.B. Allolli and Mallikarjun Awati. 2018. Effect of Bunch Feeding on Reproductive Paramaters, Bunch Parameters, Hand Parameters and Fingers Parameters in Banana cv. Rajapuri (Musa AAB). Int.J.Curr.Microbiol.App.Sci. 7(02): 756-761. doi: https://doi.org/10.20546/ijcmas.2018.702.095 